IVANA Vidović Bolt

FILOZOFSKI FAKULTET SVEUČILIŠtA U ZAGREBU

ZaGREB, HRVATSKa

ividovic@ffzg.hr

https://doi.org/10.17234/9789531755139.34

\title{
ŽIVOTINJA KAO (NE)INTELIGENTAN ČOVJEKOV PRIJATELJ
}

\begin{abstract}
Antropocentričnost i većinom negativna obilježenost frazema u sastavu kojih je naziv životinje dokazane su propitivanjem frazeoloških jedinica iz različitih aspekata u mnogim europskim jezicima. Oba su obilježja potvrda suživota čovjeka i životinje i odraz afektivna odnosa govornika prema životinjama, posebno onima s kojima je u češćem doticaju. Među frazemima s nazivom životinje posebno mjesto zauzimaju oni koji se odnose na čovjekov intelekt i u različitim se jezicima ostvaruju po istim ili vrlo sličnim modelima, a zastupljenost određene životinje ovisi o stereotipnim predodžbama svojstvenima jezičnoj i kulturnoj sredini u kojoj su se frazeološke jedinice oblikovale i ustalile.
\end{abstract}

Ključne riječi: antropocentričnost, negativna obojenost frazema, animalistički frazemi, stereotipi

\section{Antropocentričnost i negativna obojenost kao važne značajke animalističkih frazema}

Osim glavnih značajki frazema kao što su ustaljenost, cjelovitost, relativno čvrsta struktura, reproduktivnost, desemantiziranost, idiomatičnost, ekspresivnost, slikovitost, konotativno značenje, mogućnost uključenja u različite kontekste i otežana mogućnost prevođenja (Menac 1970/1971, Fink-Arsovski 2002 i dr.), animalističke frazeme ${ }^{1}$ karakteriziraju i antropocentričnost i uglavnom negativna obilježenost. Po tim se obilježjima ne razlikuju od ostalih skupina frazema poput somatskih ili fitonimnih ${ }^{2}$ kao ni frazemskih skupina nastalih prema nekim drugim mogućim kriterijima kao što su različiti koncepti, konceptualna polja ili konceptualne metafore.

U hrvatskim se frazeološkim radovima ustaljene desemantizirane sveze u sastavu kojih je naziv životinje nazivaju zoonimskim (ili zoonimnim) frazemima. U članku Nacrt za zoonomastička istraživanja (na primjeru imena konja) objavljenom u časopisu Folia onomastica Croatica Dunja Brozović Rončević i Ankica Čilaš Šimpraga ukazuju na činjenicu da se termin zoonim odnosi isključivo na ime, a ne i na naziv životinje. Imajući to na umu predlažemo da se animalističkim frazemima naziva skupina ustaljenih desemantiziranih sveza u sastavu kojih je naziv životinje (zoonimska komponenta), dio životinjskoga tijela (somatska komponenta) odnosno izvedenica (pasji, konjski i sl.). Naime, ni tijekom rasprava na skupu Animalistički frazemi u slavenskim jezicima održanom 21. i 22. ožujka 2014. u Zagrebu nije iznađen termin koji bi u frazeološkom kontekstu bio prihvatljiviji od već ustaljenog termina zoonim za naziv životinje kao frazemske sastavnice.

2 U sastavu nekih animalističkih frazema su osim zoonimske komponente i somatska i fitonimna. 
1.1. Istaknuta dva obilježja potvrdio je i korpus odabranih frazema sa spomenutim sastavnicama, a koji sadrži ukupno 641 frazem, 323 hrvatska i 318 poljskih ekscerpiranih iz različitih hrvatskih i poljskih jednojezičnih i višejezičnih općih i frazeoloških rječnika (Vidović Bolt 2011).

S obzirom na izraženu antropocentričnost frazemi su razvrstani u različita tematsko-značenjska makropolja: dob, izgled, karakterne osobine, intelektualne osobine, psihička stanja i emocije, fizička stanja, kretanje, odnos prema radu, navike, uloge i status, međuljudski kontakti i odnosi te brojnost. ${ }^{3}$

Preostali neantropocentrični frazemi (18 hrvatskih i 11 poljskih), dio su tematsko-značenjskih makropolja: doba dana, vremenski uvjeti, količina, odjevni predmeti, države, institucije i poduzeća te objekti (Vidović Bolt 2011: 134).

1.1.1. U okviru tematsko-značenjskih makropolja izdvajaju se različiti koncepti koji obuhvaćaju frazeme istoga značenjskog polja, ali nisu nužno iste strukture pa tako nemaju ni isto frazeološko ni kategorijalno značenje. Ako istom konceptu pripadaju frazemi dvaju ili više jezika, oni nisu nužno potpuno ni djelomično ekvivalentni, dakle, ne moraju udovoljavati postulatima frazeološke ekvivalentnosti. Npr. koncept NAPORAN RAD obuhvaća i ekvivalentne (i potpuno i djelomično) frazeme, ali i one kojih ekvivalentni parnjak nije potvrđen: baviti se konjskim poslom, raditi kao konj, raditi kao pas, raditi (vući, tegliti) kao vol, chodzić jak koń w kieracie, harować (orać, pracować, tyrać) jak koń, harować (pracować, tyrać) jak <dziki> osiol, harować (orać, pracować, tyrać) jak wót, pracować jak <ten $>$ wót < roboczy>.

1.1.2. Zaključak o negativnoj obilježenosti frazema nije proizišao iz moguće i ranije primijenjene trodijelne klasifikacije frazema na pozitivno, negativno i neutralno konotirane frazeme (Vidović Bolt 2004) jer je, s obzirom na specifičnost građe, ustanovljeno da je takvo razvrstavanje diskutabilno i osporivo. Naime, percepcija ovisi o pošiljateljevu i primateljevu emocionalnom pristupu informaciji koju pronosi frazeološka jedinica (Vidović Bolt 2004, Hrnjak 2006: 105). Pojedini frazemi mogu biti i ambivalentno konotirani, a na to utječu sudionici komunikacijskoga čina odnosno kontekst u kojem se frazemi pojavljuju. Primjerice frazem raditi kao konj primarno je negativne konotacije iako može opisivati i nečiji naporan rad koji svjedoči o marljivosti vršitelja radnje. Također su česti i frazemi izrazito pozitivne konotacije koji ne moraju nužno potvrđivati pozitivnu obojenost. Takva je npr. sveza vjeran kao pas koja pripada konceptu VJERNOST, ali pozitivna obilježenost može biti i predmetom rasprave ako smo skloni tezi da ljubavlju opijena osoba sigurno ni u kakvu ljubavnom zanosu ne obećava svoju vjernost izgovarajući ,i bit ću ti vjeran

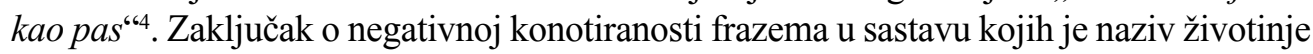
rezultat je promatranja frazema u različitim kontekstima i provjere njihova već ustaljena frazeološkog značenja.

Ovaj rad obuhvaća i frazeme koji proširuju spomenuti analizirani korpus, ali njihovo uključivanje nije rezultiralo uvođenjem novih tematsko-značenjskih makropolja.

4 Na važnost kontekstualizacije ovoga frazema ukazala mi je akademkinja Antica Menac u razgovoru u travnju 2014. na čemu joj posebno zahvaljujem. 


\section{Posebnosti animalističkih frazema kojima se opisuje čovjekov intelekt}

U paleti frazeoloških jedinica antropocentrična karaktera negativnom se obojenošću posebno ističe brojna skupina desemantiziranih sveza koje se odnose na čovjekov intelekt ${ }^{5}$. Intelekt se promatra u skladu s definicijom prema kojoj je to „čovjekova moć spoznavanja i razvijena sposobnost inteligencije da spoznaje složene pojave i proizvodi nova dostignuća; pamet, razum, um“ (HJP). Kad bismo svoje znanje o stvarnosti, pa tako i stvorenjima, temeljili isključivo na odabranoj frazeološkoj građi i frazemima $s$ nazivom domaće životinje kojima se opisuju intelektualne osobine, mogli bismo zaključiti da je ljudski svijet gotovo lišen čak i ,zrna mudrosti' jer pozitivno konotirani primjeri izostaju. Potvrđene su samo frazeološke jedinice kojima se opisuje glupa osoba, osoba intelektualno skromnih sposobnosti i ograničenoga spoznajnog kapaciteta. $\mathrm{Na}$ frazeme takvoga značenja nadovezuju se i oni koji se također mogu rabiti u istome odnosno sličnome kontekstu jer ih povezuje pomanjkanje inteligencije ${ }^{6}$ ili pak potpuni izostanak uočljiv na razini pamćenja, shvaćanja, smijanja. ${ }^{7}$ Visok stupanj zastupljenosti negativno konotiranih frazema u skladu je sa zaključkom Anne Pajdzińske (1991: 18) u kojem ističe kako: „mnogo više frazema izražava negativno nego pozitivno vrednovanje. Sinonimni nizovi koji opisuju negativne pojave bogatiji su od nizova koji opisuju pozitivne pojave.”.

2.1. U sastavu frazema kojima se upućuje na čovjekove intelektualne osobine uočljive u raznolikim aspektima njegova življenja i ponašanja pojavljuju se nazivi različitih domaćih životinja. U hrvatskome su to bik, guska, kokoš, konj, koza, magarac, magare, tele, telac i vol, a u poljskome baran, byk, cielę, gęś, kura, koza, koziol, krowa, osiot, owca, świnia i wót.

Uglavnom su to, dakle, leksemi koji u svojem prenesenom značenju upućuju na glupu osobu, ali su zastupljeni i leksemi kojima to značenje nije svojstveno (npr. pile i pače) ili barem nije dominantno (npr. svinja).

Podudarnost zoonimskih sastavnica frazema odabranoga koncepta (iznimke su leksemi koziot, koń, ovan i ovca), ukazuje nam i na identičnost stereotipa o životinjama u govornika obaju jezika. Iako konotativno značenje svih leksema nije povezano $\mathrm{s}$ intelektualnom ograničenošću, prisutnost u frazemima onih leksema kod kojih takvo

5 O intelektu u hrvatskoj, poljskoj i ruskoj frazeologiji v. Agnieszka Spagińska-Pruszak (2005).

6 Inteligenciju promatramo kao skup ,sposobnosti shvaćanja i laganog snalaženja u novim prilikama, sposobnost otkrivanja zakonitosti u odnosima među činjenicama i rješavanju problema; oštroumnost, pamet, bistrina duha“, odnosno ,ukupnost sposobnosti shvaćanja i uočavanja činjenica u neposrednom snalaženju i borbi za opstanak živih bića [inteligencija kukca; inteligencija ribe]“ (HJP).

7 U istraživanje nisu uključeni frazemi kojima se opisuje psihičko stanje. Izostavljeni su i frazemi koji primarno opisuju čovjekove postupke s uključenim semom nesmotrenosti, ograničenog intelektualnog potencijala, trajnoga ili trenutačnoga karaktera, npr. baciti / bacati biser (biserje) pred svinje i rzucać perty przed świnie 'dati / davati (reći / govoriti) štogod lijepo onomu koji to ne shvaća i/ili toga nije vrijedan', musti jarca u rešeto, kozła doić <próżno> 'raditi uzaludan posao', dati vuku kozliće pasti (čuvati), povjeriti ovce vuku itd. 'lakomisleno povjeriti što nepouzdanoj osobi' itd. 
obilježje u prenesenome značenju izostaje, nije umanjilo ekspresivnost frazeološke jedinice. Neki su od leksema i rodno obilježeni - guska i gęś, kokoš i kura te koza u svom metaforičkom značenju upućuju na glupu žensku osobu, a tele, telac, magarac na mušku.

2.2. Među frazemima u kojima se ogleda stereotipna predodžba o „glupim“ životinjama (Spagińska-Pruszak 2005, Rak 2007, Szerszunowicz 2006, 2011) posebno su ekspresivne sveze poredbene strukture kod kojih je u A-dijelu pridjevska sastavnica glup, glupa odnosno glupi, głupia, a nakon poredbenog veznika slijedi naziv životinje: glup kao konj, glup kao magarac, glup kao magare, glup kao tele, glup kao vol ${ }^{8},<$ glupa $>$ kao guska, głupi jak baran, głupi jak ciele, głupi jak kozioł, głupi jak osioł, glupi jak pies, głupia jak gęś. Kod takvih je sveza prepoznatljiva i uporabno česta stilska figura poredba. Poredbenim frazemima i poredbi kao stilskoj figuri, osim strukture zajednička je i slikovitost, a razlikuju se po tome što navedene desemantizirane sveze riječi ne nastaju spontano, nego su se čestom i dugotrajnom upotrebom potpuno frazeologizirale (Bagić 2012: 256) i kao takve odraz su stereotipa nastalog na prototipnim obilježjima (Habrajska 1998: 118). Kurkowska i Skorupka (2001: 158) poredbene frazeme nazivaju i stereotipnim svezama jer su se ustalile predodžbe prema kojima je npr. guska glupa, tele glupo, vuk gladan i opasan, pas vjeran i sl.

Pridjevska sastavnica intenzivira značenje i frazema neporedbene strukture: glupie (marynowane) ciele, głupia gęś, głupia koza, glupia krowa, głupia świnia. Za razliku od poljskih, u hrvatskim frazeološkim rječnicima nisu navedene sveze nastale prema modelu - glup + naziv životinje.

2.3. U nekoliko neporedbenih frazema česta je somatska sastavnica i to u funkciji intenzifikatora simboličkoga potencijala kad stoji uz pridjevsku izvedenicu naziva životinje. Najčešći somatizam je glava odnosno glowa, zatim mozak odnosno mózg ili móżdżek (hrv. mali mozak). I frazemi hrvatskoga jezika potvrđuju da se u različitim ,jezicima nerazboriti i glupi ljudi opisuju pomoću jedinica sa zoonimskim sastavnicama kojima je zajednička metafora GLAVA JE SPREMNIK, ali se zoonimi razlikuju u pojedinim jezicima.“ (Szerszunowicz 2011: 216). Glava nije samo somatizam, odnosno u odabranim frazemima somatska sastavnica, nego je znak pameti i inteligencije, tj. „mjera za razum“ (Spagińska-Pruszak 2005: 137), a veličina dijela tijela predstavlja „veličinu“ čovjekovih intelektualnih mogućnosti.

2.4. Spomenuta se metafora ostvaruje u nekoliko modela koji su potvrđeni i u drugim jezicima, ali s određenim razlikama svojstvenima propitivanom frazeološkom fondu. Sličnu klasifikaciju navodi npr. Szerszunowicz (2006: 204), ali s većim brojem modela jer su osim poljskih frazema razmatrani i talijanski i engleski. Ovdje izdvajamo modele potvrđene najmanje dvama frazemima hrvatskoga i poljskoga jezika:

$\overline{8}$ Prema Ž. Fink (2002: 32) i to je potvrda da je aseksualnost našla odraza u frazeologiji. 
a) glup + poredbeni veznik + zoonim - glup kao konj, glup kao magarac, glup kao magare, glup kao tele, glup kao vol, <glupa> kao guska, glupi jak baran, glupi jak ciele, głupi jak koziol, głupi jak osiot, głupi jak pies, głupia jak gęś

b) pridjevska zoonimska izvedenica + somatizam u nominativu - pileća glava, kokošji mozak, pileći mozak, barania głowa, ośla głowa, barani łeb, kurzy móżdżek (rozum), mózg (rozum) cielęcy

c) somatizam + zoonim u genitivu - glowa osła, glowa wolu

d) glup + zoonim u nominativu - glupie (marynowane) ciele, glupia koza, glupia krowa, glupia owca

e) zoonim u nominativu + pridjev / glagolski pridjev trpni - osiot dardanelski, osiot kwadratowy (do kwadratu), osiot patentowany, osiot skończony

f) razumjeti se // znać się + poredbeni veznik + zoonim + prijedlog + naziv povrća ili začina ili naziv mjerne sprave - razumjeti se u što kao koza u peršin (peršun), razumjeti se u što kao magarac u kantar, razumjeti se u što kao magare u kantar, znać się na czymś jak (tyle co) kura na pieprzu, znać się na czymś jak koza na pieprzu

g) biti + izvedenica naziva životinje u genitivu + pamet u genitivu - biti pileće pameti, biti pačje pameti

h) gledati $i$ sl. + poredbeni veznik + naziv životinje + prijedlog + pridjev + imenica - gledati (buljiti, blenuti i sl.) u koga, u što kao tele u šarena (nova) vrata, gapić się (patrzeć) na coś, na kogoś jak cielę na malowane (nowe) wrota, patrzé́ jak wót na malowane wrota.

2.5. Frazemi barania głowa, barani łeb, ośla głowa, głowa osła i glowa wolu značenja 'glupa osoba, osoba skromnih intelektualnih mogućnosti' primjeri su intenzifikacije značenja ostvarene simbiozom metaforičkoga značenja frazemske zoonimske komponente i slike dijela velikog tijela životinje (baran (hrv. ovan), osiot (hrv. magarac), wót (hrv. vol)).

U frazemima kokošji mozak, kurzy móżḋ̇ek (rozum), pileća glava, pileći mozak istoga značenja veličina somatizma proporcionalna je intelektualnom kapacitetu te je somatska komponenta signal manjega kvocijenta inteligencije (mali mozak = glupa osoba). Naravno, ključan je i simbolički potencijal zoonimske komponente.

Frazemom kokoš je pamet (mozak) pozobala komu također se opisuje intelektualno ograničena osoba. Međutim, na formiranje značenja nije utjecalo samo pejorativno značenje sastavnice kokoš nego i slika ljudskoga mozga koji zbog male veličine kokoš može lako i brzo pozobati. Komponenta pamet metonimija je somatske sastavnice mozak.

Primjeri sa sastavnicom pileći i pačji potvrda su kako metaforičko značenje određene životinje nije uvijek podudarno sa značenjem frazema u kojem se pojavljuju jer sveze imati pileću pamet, biti pileće pameti, biti pačje pameti upućuju na intelektualno ograničena čovjeka iako ni pile ni pače ne pronose simboliku gluposti. Štoviše, pile uživa poseban status u objema sredinama i to ponajprije među djecom, a poznato je da je simbol nade i novoga života. Te sveze potkrjepljuju tvrdnju Joanne Szerszunowicz (2011: 44) da ,neki nazivi mogu izazvati negativnu konotaciju unatoč pozitivnoj slici ustaljenoj u kulturi“.

Svim frazemima sa somatskom komponentom opisuje se osoba lišena sposobnosti zaključivanja, skromnih umnih sposobnosti odnosno ona koja sporo misli. 
2.6. Ekspresivnosti pridonose i glagolske sastavnice u frazemima gledati (buljiti, blenuti i sl.) u koga, u što kao tele u šarena (nova) vrata, gapić się (patrzeć) na coś, na kogoś jak cielę na malowane (nowe) wrota, patrzeć jak wól na malowane wrota, gapić się (patrzeć się, wlepiać wzrok) jak pies, koje opisuju čovjekovo nerazumijevanje, neshvaćanje, intelektualnu nesposobnost. Glagolskim sastavnicama buljiti i blenuti kao i gapić się dočarava se način gledanja, piljenja što uključuje i sem tuposti i nerazumijevanja.

Dosadašnja istraživanja animalističkih frazema različitih jezika pokazuju kako najlošiji status ima upravo pas (Mosiołek 1992, Szerszunowicz 2011, Vasung 2009, Vidović Bolt 2011). Čovjekov se skroman intelekt, uz frazem glupi jak pies, opisuje i poljskom svezom s istom komponentom - gapić się (patrzeć się, wlepiać wzrok) jak pies u značenju 'buljiti, blenuti, promatrati s nerazumijevanjem'.

Čovjekov pogled lišen razumijevanja dočaravaju i frazemi teleći pogled, kokošji pogled, cielęce spojrzenie čiju ekspresivnost naglašavaju izrazito pejorativno obilježene zoonimske sastavnice dok je na intenzitet značenja frazema barani wzrok utjecala veličina životinje.

2.7. O važnosti konotativnoga značenja zoonimske sastavnice svjedoči i frazem teleći osmijeh jer je zoonim izrazito negativno obojen. Frazemom se opisuje čovjekov osmijeh koji je odraz nerazumijevanja izrečenog (šale, doskočice i sl.).

2.8. Nekompetentnost ljudi opisuju frazemi ironična prizvuka kojih je značenje suprotno od značenja glagolske sastavnice razumjeti se u što kao koza u peršin (peršun), razumjeti se u što kao magarac u kantar ${ }^{9}$, razumjeti se u što kao magare u kantar, znać się na czymś jak (tyle co) kura na pieprzu, znać się na czymś jak koza na pieprzu. Sve su ustaljene desemantizirane sveze motivirane negativno konotiranim statusom samoga leksema, a živopisnim motivima upućenih životinja postiže se atraktivnost frazema što pridonosi njihovoj učestalijoj uporabi. Frazem u sastavu kojega je komponenta wót (hrv. vol) - chodzić jak wót koto apteki 'uopće se ne razumjeti $u$ što' također je odraz negativnoga simboličkog statusa životinje zato što nam dočarava sliku nesposobnoga vola koji hoda oko ljekarne jer ne zna što treba napraviti odnosno što se od njega očekuje da napravi.

2.9. U hrvatskom i poljskom jezično-kulturnom kontekstu svinja je iznimno negativno konotirana životinja, ali o takvom statusu svjedoče i mnogi drugi jezici u kojima „bez sumnje ima najgoru poziciju među domaćim životinjama” (Peisert 2003: 149). Njezina je pozicija usporediva sa psom, ali psa odlikuju i neke pozitivne osobine, kako one, doista mu svojstvene (npr. vjernost), tako nerijetko, opravdano ili ne, pripisivane (npr. lažljivost, ljubomora).

Osim u frazemu glupia świnia, zoonim świnia (hrv. svinja) komponenta je i sveze świnie powinien pasać motivirane klišeiziranom slikom o deprecijativnom statusu svinjara, osobe koja zbog vlastite nesposobnosti i skromnih intelektualnih predispozicija mora čuvati tako omražene životinje i obavljati tako ponižavajući posao. Evanđelje po Luki $($ Lk 15,15) također spominje prispodobu o rasipnome sinu kojega šalju

Kantar je ručna vaga za mjerenje, bez utega i plitica, koja se drži u jednoj ruci. 
da u polju čuva svinje, što se smatra(lo) velikom sramotom jer su se tim poslom bavili samo pripadnici najnižega društvenog sloja (Vidović Bolt 2011: 109).

\section{Odnos čovjeka i životinje - frazeološki odraz}

Propitivanje prisutnosti naziva domaćih životinja $u$ sastavu negativno konotiranih frazema obaju jezika potvrđuje njihovu dominantnu zastupljenost u odnosu na ostale životinje. Objašnjenje koje se gotovo laički nameće i nije nužno uvjetovano sociološkim i kulturološkim (pred)znanjem jest da je takav omjer rezultat specifična odnosa korisnika jezika (govornika) prema onim vrstama životinja s kojima je često u kontaktu neovisno o tome je li riječ o stanovniku urbane ili ruralne sredine. Takvi frazemi odražavaju čovjekov afektivni odnos prema životinjama s kojima je češće u doticaju i koje je uspio podrediti svojim željama i potrebama (životinje su čuvari, radna snaga, ljubimci i sl.). Aristokratski pristup životinji uočljiv je u procesu tzv. dvostruke metaforizacije (Vidović Bolt 2007), zoomorfističkih postupaka - dodjeljivanja životinji ljudskih osobina i obilježja (ljubomora, zavist, dobar sluh i sl.), neovisno o tome jesu li joj svojstvena ili ne, te kovanjem novih frazeoloških sveza koje su, kao što pokazuju i ovdje navedeni primjeri, uglavnom antropocentrični. Izdvojene sveze motivirane su čovjekovim iskustvom još iz vremena kad je bio više u kontaktu s prirodom, s florom i faunom i njihovim predstavnicima, ali udaljavanje od životinjskoga svijeta u moderno doba, uočljivo u sve češćoj nemogućnosti raspoznavanja i razlikovanja tih stvorenja, ne utječe na zatiranje postojećih sveza niti rezultira gubitkom motivacije za kreiranje novih. Sukladno je tomu ,stereotipni model antropocentričan“ i ,,izrasta iz zlouporabe jezika i životinjskih kategorija koje su prosuđene prema direktnoj korisnosti/nekorisnosti čovjeku.“ (Bertoša 1999: 6). Bartmiński (2007: 96) tvrdi da ,stereotipi o životinjama i biljkama pripadaju najstarijima i imaju posebno kulturno značenje“" pri čemu upravo domaće životinje imaju istaknuto mjesto u negativnoj prosudbi unatoč čovjekovoj koristi koju od njih ima.

3.1. Poljskim frazeološkim fondom s primjerima koji upućuju na osobu skromnih intelektualnih mogućnosti dominiraju sveze sa sastavnicom osioł (hrv. magarac): osiot dardanelski, osioł do czwartej potęgi, osioł do kwadratu (czwartej potęi), osioł kwadratowy, osioł patentowany, osioł skończony. O negativnom simboličkom potencijalu samoga leksema svjedoči frazem zachowywać się jak osioł u značenju 'ponašati se glupo'. Tvrdnju da čovjek životinji s kojom je češće u kontaktu spremnije pripisuje različita negativna obilježja, opovrgava odabrana skupina jer je među njima upravo magarac najzastupljeniji. Naime, iako je i prema poljskoj zoološkoj klasifikaciji magarac domaća životinja, ipak je riječ o Poljacima egzotičnoj životinji, jer ne nastanjuje poljski teritorij.

Je li razlog za takvu bliskost i povezanost biblijske provenijencije (magarac uz vola stoji uz uzglavlje tek rođenoga Isusa) ili su doista pisci basni ${ }^{10}$ te autori različitih umjetničkih ostvarenja odigrali ključnu ulogu u približavanju magarca i stanovnicima

10 Magarac je prisutan u 30 Ezopovih basni gdje je, kao i kod drugih autora, često predmet izrugivanja zbog svojega izgleda (duge uši, nespretan hod) te pripisanog mu hrapava glasa (Kopaliński 2003: 290). 
prostora u kojima on ne obitava, nije lako jednoznačno odgovoriti. Nedvojbeno je da se magarcu glupost pripisuje kao značajna, gotovo najvažnija osobina i da je to dodijeljeno mu metaforičko značenje razlog tako veliku broju frazema sa sastavnicom magarac unutar koncepta INTELEKTUALNA OGRANIČENOST (Vidović Bolt i Szerszunowicz 2014: 488). Kad bi konotativno značenje samoga zoonima bilo pozitivno, frazemi osiot do kwadratu (czwartej potegi) i osiol kwadratowy, a koje Spagińska-Pruszak (2005: 214) naziva „matematičko-tehničkim frazemima”, mogli bi značiti i ,jako mudra osoba“. U prepoznavanju značenja frazema osiot dardanelski 'glupa (umno) ograničena osoba, osoba koja nema sposobnost zaključivanja i/ili koja sporo misli’ također je presudno konotativno značenje samoga zoonima, poznavanje stereotipa, ali i znanje o svijetu. Naime, pozadinska nam slika otkriva Dardanelski tjesnac i upravo je slika uskoga prolaza bila poticaj u kreiranju frazeološke sveze takva značenja.

3.2. U predstavljenim su primjerima uočljive stereotipne metafore ${ }^{11}$ zasnovane na konotacijama i povezane s različitim osobinama pripisanima životinjama (simbolička funkcija) dok stvarne (ikonička funkcija) ${ }^{12}$, barem znanstveno utemeljene, izostaju. Da stereotipe teško iskorjenjuju čak i znanstveno utemeljene činjenice potvrđuje nam negativna konotacija leksema guska u frazemima <glupa> kao guska, głupia jak gęś, głupia gęś. U obama se jezicima guska doživljava nadasve glupom životinjom ,a u stvarnosti je osim vrane i papige najinteligentnija životinja“" (Spagińska-Pruszak 2005: 191) pa se takvi frazemi mogu smatrati i ,antiprimjerima“ (Rak 1997: 113).

Izostanak frazema s istom sastavnicom rezultat je različitih stereotipa što potvrđuje da je ,simbolika životinja zapisana u jezičnom i kulturnom kodu različitih društava odraz sličnog ili različitog načina života, tradicije, vjerovanja“ (Peisert 2003: 149). Primjera radi, krava u Indiji uživa kultni status svete životinje, mrav je u europskoj kulturi uglavnom simbol marljivosti dok se u Indiji kretanje mrava smatra potpuno besmislenim (Szerszunowicz 2011: 37).

\section{Prema zaključku}

S obzirom na bliskost sa životinjom čovjek je sebi (neopravdano!) dodijelio pravo da joj pripisuje najrazličitija negativna obilježja. Takvi su postupci popraćeni ,aristokratskim“ pristupom životinji i rezultiraju negativno konotiranim, nerijetko pejorativnim pa i deprecijativnim frazemima koji se odnose uglavnom na čovjeka i pritom diskreditiraju životinju (Spagińska-Pruszak 2005: 197) isticanjem njezinih negativnih (katkad stvarnih, češće izmišljenih) osobina životinje (usp. simbolička i ikonička funkcija). U sastavu su predstavljenih frazema životinje koje obavljaju funkcije za koje, tvrdi se, nije potreban gotovo nikakav intelektualni angažman (nesu jaja, obavljaju teške fizičke poslove i sl.) (Denčeva 2013: 297).

\footnotetext{
11 O stereotipnim metaforama koje se rasprostranjuju i ukorjenjuju u jezicima i kulturama u kojima se rabe, a posebno u frazeologiji opširnije: Kurkowska i Skorupka (2001), Spagińska-Pruszak (2005), Szerszunowicz (2011).

12 O ikoničkoj i simboličkoj funkciji više: Dobrovol'skij i Piirainen (2005).
} 
Izdvojimo li sveze sa sastavnicama pileći i pačji jer, kao što je već istaknuto, somatizmi pile i pače nisu nositelji negativnoga simboličkog potencijala, može se uočiti da je negativnu konotiranost ustaljenih desemantiziranih sveza odredilo pejorativno metaforičko značenje sastavnice - zoonimskog leksema (naziv domaće životinje) ${ }^{13}$. Njima pripisane osobine, a ovdje propitane uglavnom su negativne, utjecale su i na formiranje frazeoloških jedinica. Takve frazeme uvredljiva karaktera u čijem sastavu je naziv životinje ili pak izvedenica, a koji se odnose na čovjeka, Szerszunowicz (2006: 203) naziva fauničnim frazeoinvektivama (frazeoinwektywy fauniczne).

Čovjek je skloniji, spremniji, a zasigurno i smioniji domaćoj životinji pripisati svoje ljudske osobine, a ponajprije slabosti i mane, nego divljim životinjama kojima se divi $\mathrm{i}$ istodobno ih se boji, ali i od kojih zazire jer ih nije uspio ukrotiti i sebi podčiniti. Time pokazuje svoju slabost u odnosu na životinju, ali i svojevrsnu ovisnost o njoj. Takav je pristup i razumljiv s obzirom na međusobnu upućenost pa čak i nezanemarivu, pogotovo nekadašnju, ovisnost - čovjek ne može bez životinje, a nerijetko ni ona bez njega. Životinja je čovjeku izvor hrane, odjeće, ali i zaštitnik, vjeran pratitelj te pomoćnik u različitim poslovima. Čovjekova se važnost u životu životinja ne smije podcijeniti jer im pruža i utočište i pomoć, naravno, ovisno o okolnostima u kojima se nalaze.

Iako ne nalazimo potvrdu za frazem kojim se opisuje inteligentna osoba, a u sastavu kojega je domaća životinja, skloni smo zaključku da odgovor na pitanje glup, gluplji, homo ili animal? - ide u prilog životinji kao inteligentnom stvorenju koje se priklanja čovjeku kad procijeni da ga može zaštititi ili mu biti od koristi. Značajan broj animalističkih frazema u kojima je čovjek glupost pripisao životinji dokaz je također čovjekove neupućenosti (Szerszunowicz 2011: 50, 213) i ignoriranja novih znanstvenih spoznaja, a zadržavanje nekadašnjih, izrazito stereotipiziranih. Kwirina Handke (1992: 182) podsjeća da „odavno znamo da je magarac jedna od najmudrijih životinja (...).“. Možemo dodati da čovjek, ljut na magarca zbog njegova „čvrstog“ karaktera, „nesalomljivosti“, ustrajnosti u namjeri da se poštuje njegovo trenutno raspoloženje a koju čovjek tumači kao tvrdoglavost i glupost, rjeđe kao neposlušnost, jer dovodi u pitanje i njegov autoritet, ustrajava u njegovanju postojećih stereotipa.

Frazemi zasnovani na višestoljetnim stereotipima odraz su tradicije da čovjek o pripadnicima svoje vrste govori skriven iza maske (Bartmiński 2007: 96) različitih životinja. I dok u frazeološkom kontekstu opravdano govorimo o dvostrukoj metaforizaciji, u realnom svijetu, kako smo istaknuli, uočavamo višestruku ovisnost, bez obzira na činjenicu što je upravo dar govora najjači čovjekov adut i rezultira novim svezama nastalima po uzoru na različite predstavljene modele.

13 Pokušaj da se spomenutom i analiziranom korpusu domaćih životinja pridodaju i ostale, ranije neuključene životinje (ribe, divlje životinje itd.) nije promijenio polaznu točku u promatranju spomenutog problema. 


\section{LITERATURA}

Bagić, Krešimir. 2012. Rječnik stilskih figura. Zagreb: Školska knjiga.

Bartmiński, Jerzy. 2007. Stereotypy nie mieszkaja w języku. Studia etnolingwistyczne. Lublin: Wydawnictwo Uniwersytetu Marii Curie Skłodowskiej.

Bertoša, Mislava. 1999. Ljudi, stereotipi, životinje. Lingvistički pristup stereotipima o životinjama na primjeru Esopovih basana. Diplomski rad. Filozofski fakultet. Sveučilište u Zagrebu. Zagreb.

Brozović Rončević, Dunja; Čilaš Šimpraga, Ankica. Nacrt za zoonomastička istraživanja (na primjeru konja). Folia onomastica Croatica. 17: 37-58.

Cocagnac, Maurice. 2002. Biblijski simboli. Teološki pojmovnik. Zagreb: antiBARBARUS.

Denčeva, Diliana. 2013. Olej, kapusta, kalosze. Inteligencja i głupota w polskich i bułgarskich związkach frazeologicznych. Postscriptum polonistyczne 2 (12). 295-301.

Dobrovol'skij Dmitrij O.; Piirainen Elisabeth. 2005. Figurative Language: Cross-cultural and Cross-linguistic Perspective. Current Research in the Semantics/Pragmatics Interface. 13. Amsterdam: Elsevier.

Fink-Arsovski, Željka. 2002. Poredbena frazeologija: pogled izvana i iznutra. Zagreb: FF press.

Habrajska, Grażyna. 1998. Prototyp - stereotyp - metafora. U: Język a kultura. Stereotyp jako przedmiot lingwistyki. Teoria, metodologia, analizy empiryczne. t. 12. Anusiewicz, Janusz; Bartmiński, Jerzy (red.). Wrocław: Towarzystwo Przyjaciół Polonistyki Wrocławskiej. 116-123.

Handke, Kwiryna. 1992. Ignorancka potoczność, U: Język a kultura. Potoczność w języku i kulturze. t. 5. Anusiewicz, Janusz; Nieckula, Franciszek (red.). Wrocław: Wiedza o kulturze. 179-191.

Hansen-Kokoruš, Renate. 1996. Magarac i konj u svjetlu njihovih frazeoloških osobina. Na materijalu ruskoga, hrvatskoga i njemačkoga jezika. Filologija. 27: 43-52.

Hrnjak, Anita. 2006. Neke pragmatičke osobitosti supstantivnih frazema koji se odnose na čovjeka (na primjeru hrvatskih i ruskih frazema). U: Slavenska frazeologija i pragmatika. Fink Arsovski, Željka; Hrnjak, Anita (red.). Zagreb: FF press. 105-109.

Hyams, Edward. 1974. Zwierzęta w stużbie człowieka. Warszawa: Państwowe Wydawnictwo Naukowe.

Kurkowska, Halina; Skorupka Stanisław. 2001. Stylistyka polska. Zarys. Warszawa: Wydawnictwo Naukowe PWN.

Menac, Antica. 1970/1971: O strukturi frazeologizama. Jezik. XVIII. 1: 1-4.

Mosiołek, Katarzyna. 1992. Stereotypy psa zawarte w języku polskim. Poradnik Językowy. 4. 301-304.

Menac, Antica. 2007. Hrvatska frazeologija. Zagreb: Knjigra.

Pajdzińska, Anna. 1991. Wartościowanie we frazeologii. U: Język a kultura. Wartości w języku $i$ tekście. t. 3. Puzynina, Jadwiga; Anusiewicz, Janusz (red.). Wrocław: Wiedza o kulturze. 15-28. 
Peisert, Maria. 2003. Sus domesticus - zwierzę, którego nazwy używać nie wypada. U: Język a kultura. Opozycja homo - animal w języku i kulturze. t. 15. Dąbrowska, Anna (red.). Wrocław: Wydawnictwo Uniwersytetu Wrocławskiego. 149-155.

Rak, Maciej. 2007. Językowo-kulturowy obraz zwierząt utrwalony w animalistycznej frazeologii gwar Gór Świętokrzyskich i Podtatrza (na tle porównawczym). Kraków: Wydawnictwo Scriptum.

Spagińska-Pruszak, Agnieszka. 2005. Intelekt we frazeologii polskiej, rosyjskiej i chorwackiej. Z problematyki językowego obrazu świata. Łask: Oficyna Wydawnicza LEKSEM.

Szerszunowicz, Joanna. 2007. Frazeoinwektywy fauniczne nazywajace głupote $w$ ujęciu konfrontatywnym (na materiale współczesnego języka polskiego $w$ porównaniu $z$ angielskim i włoskim). U: Slavenska frazeologija i pragmatika. Fink Arsovski, Željka; Hrnjak, Anita (red.). Zagreb: FF press. 203-208.

Szerszunowicz, Joanna. 2011. Obraz człowieka w polskich, angielskich $i$ włoskich leksykalnych i frazeologicznych jednostkach faunicznych. Białystok: Wydawnictwo Uniwersytetu w Białymstoku.

Vidović Bolt, Ivana. 2004. Frazemi sa zoonimskom sastavnicom u hrvatskom i poljskom jeziku. Doktorska disertacija. Filozofski fakultet. Sveučilište u Zagrebu. Zagreb.

Vidović Bolt Ivana. 2007. Metaforika zoonima u hrvatskoj frazeologiji. U: Kulturni bestijarij. Marjanić, Suzana; Zaradija Kiš, Antonija (red.). Zagreb: Institut za etnologiju i folkloristiku - Hrvatska sveučilišna naklada. 403-424.

Vidović Bolt, Ivana; Szerszunowicz, Joanna. 2014. Językowo-kulturowy obraz osła w języku chorwackim i polskim. Stałość i zmienność w językach i kulturach świata I. Dziadosz, Dorota; Krzanowska, Agnieszka; Szlachta, Agnieszka (red.). Szczecin: Volumina pl Daniel Krzanowski. 481-499.

Vidović Bolt, Ivana. 2011. Životinjski svijet u hrvatskoj i poljskoj frazeologiji I, Zagreb: Hrvatska sveučilišna naklada.

\section{RJEČNICl}

Bańko, Mirosław. 2004. Słownik porównań. Warszawa: Polskie Wydawnictwo Naukowe PWN.

Fink Arsovski, Željka et al. 2006. Hrvatsko-slavenski rječnik poredbenih frazema. Zagreb: Knjigra.

Kopaliński, Władysław. 2003. Słownik mitów i tradycji kultury. Warszawa: Oficyna Wydawnicza Rytm.

Matešić, Josip. 1982. Frazeološki rječnik hrvatskoga ili srpskog jezika. Zagreb: Školska knjiga.

Menac, Antica; Fink-Arsovski, Željka; Venturin, Radomir. 2003. Hrvatski frazeološki rječnik. Zagreb: Naklada Ljevak.

Moguš, Milan; Pintarić, Neda. 2002. Słownik polsko-chorwacki. Poljsko-hrvatski rječnik. Zagreb: Školska knjiga.

Müldner-Nieckowski, Piotr. 2003. Wielki słownik frazeologiczny języka polskiego. Warszawa: Świat Książki. 
Skorupka, Stanisław. 1989. Słownik frazeologiczny języka polskiego. Warszawa: Wiedza Powszechna.

Uniwersalny słownik języka polskiego. 2003. Dubisz, Stanisław (red.). t. I-IV. Warszawa: Wydawnictwo Naukowe PWN.

\section{Mrežni izvori:}

Hrvatski jezični portal: http://hjp.novi-liber.hr/ [HJP]

Vasung, A. 2009. Frazemi sa sastavnicama pas i mačka u bugarskom i hrvatskom jeziku (semantička analiza). Philological Studies 2./ http://philologicalstudies.org/ dokumenti/2009/vol2/3/39.pdf Datum posjeta: 28. 4. 2014.

\section{SUMMARY}

\section{ANIMAL AS A(NON) INTELLIGENT MAN'S FRIEND}

Anthropocentricity and mostly negative connotations of idioms with an animal lexeme component have been established by analyzing the connection between the two features from different aspects in many European languages. Both features are a confirmation of co-existence between humans and animals and a reflection of the affective relationship between the speaker and the animals, especially those with whom he or she has a more frequent contact. Special positions among animal idioms have those which relate to human intellect and are in different languages formed by the same or very similar models. On the other hand, the representation of animals that appear depends on reflected stereotypical images inherent to the linguistic and cultural environment in which the idiomatic structures have been formed and conventionalized.

Key words: anthropocentricity of idioms, animal idioms, stereotypes, intellect 